\begin{tabular}{lccc} 
& GOSPODARKA & SUROWCAMI & MINERALNYMI \\
\hline Tom 28 & 2012 & Zeszyt 3 \\
& DOI 10.2478/v10269-012-0025-z &
\end{tabular}

\title{
Możliwości sejsmicznej identyfikacji stref akumulacji gazu w utworach węglanowych cechsztynu monokliny przedsudeckiej
}

\section{Wprowadzenie}

Monoklina Przedsudecka jest rejonem, w którym zlokalizowane są złoża węglowodorów, ale także rud miedzi. Cechą wspólną tych złóż jest ich lokalizacja w obrębie węglanowych utworów cechsztynu.

Złoża gazu występują w utworach węglanowych cyklotemów PZ1 (w wapieniu podstawowym Ca1) oraz PZ2 (w dolomicie głównym Ca2). Lokalizacja złóż jest ściśle związana ze strefami sedymentacji węglanów. Złoża występują przede wszystkim w obrębie stref barierowych oraz podnóża platform węglanowych (Pikulski 2004). Przykładem złoża zlokalizowanego w strefie barierowej może być złoże Kościan w wapieniu cechsztyńskim Ca1. Natomiast przykładem złoża zlokalizowanego u podnóża platformy może być złoże Lubiatów (dolomit główny Ca2).

Podstawową metodą badawczą stosowaną do lokalizacji złóż węglowodorów, także na obszarze Monokliny Przedsudeckiej, są powierzchniowe sejsmiczne badania refleksyjne. Ich sukcesy poszukiwawcze wynikają przede wszystkim z faktu zmiany parametrów petrofizycznych górotworu pod wpływem nasycenia przestrzeni porowej gazem, a nie jak zwykle bywa wodą złożową. Przy nasyceniu gazem zmniejsza się nawet o 30\% wartość prędkości propagacji fal podłużnych, zmniejsza się również gęstość objętościowa. Na skutek tego w rejestrowanym zapisie sejsmicznym widoczne są strefy zapisu anomalnego. Ich powiązanie ze złożami gazu, czyli złożowa interpretacja danych sejsmicznych, oparta jest na analizie DHI (Direct Hydrocarbon Indicator).

* Dr inż. ** Prof. dr hab. inż., AGH Akademia Górniczo-Hutnicza, Katedra Geofizyki, Kraków; e-mail: geodec@agh.edu.pl, pietsch@agh.edu.pl 
Złoża miedzi związane są z granicą cechsztyn/czerwony spągowiec. Poza łupkiem miedzionośnym, który zlokalizowany jest w spąu cyklotemu PZ1 okruszcowanie występuje też w spagowej partii wapienia cechsztyńskiego Cal oraz w stropie białych piaskowców BP czerwonego spagowca.

We wrześniu 2009 roku, prowadząc roboty górnicze związane z udostępnianiem nowej partii złoża, ZG Rudna KGHM Polska Miedź S.A. natrafił w chodniku T169a na „pułapkę gazową" o niewielkiej kubaturze, lecz dużym ciśnieniu. W wyniku spękania skał wywołanego robotami strzałowymi, sprężony gaz spowodował wyrzut rozdrobnionego materiału skalnego do chodnika (Zorychta 2010). W związku z powstałym zagrożeniem wyrzutami gazów i skał wstrzymano roboty górnicze do czasu wyjaśnienia przyczyn wyrzutu oraz określenia ewentualnych miejsc potencjalnej koncentracji gazu. Biorąc pod uwagę doświadczenia w sejsmicznej lokalizacji złóż gazu w węglanach PZ1 i PZ2 wykonane zostało zdjęcie sejsmiczne 3D, którego celem było rozpoznanie układu strukturalnego i próba lokalizacji stref o zmienionych, pod wpływem nasycenia gazem, parametrach petrofizycznych w spagowych utworach cechsztynu - w dolomitach wapienia cechsztyńskiego Ca1. Podjęto również badania metodą tomografii sejsmicznej w partiach złoża zagrożonych wyrzutami gazów i skał (Pilecki i in. 2012).

W prezentowanej pracy przedstawiono i porównano sejsmiczne odwzorowanie nasycenia gazem ,pułapek” zlokalizowanych w strefach o bardzo różnej budowie geologicznej: typowej barierze węglanowej (złoże Kościan w Ca1), w strefie podnóża platformy węglanowej (złoże Lubiatów w Ca2) oraz porowatej/szczelinowatej strefie dolomitu Ca1 w rejonie wyrzutu gazu, który miał miejsce w KGHM ZG Rudna.

\section{Sejsmiczne wskaźniki budowli węglanowych nasyconych gazem}

Ze względu na duże urozmaicenie dna basenów sedymentacyjnych cechsztynu węglanowe osady cyklotemów PZ1 i PZ2 wykształciły się w zróżnicowanych strefach paleogeograficznych: basenowej, podnóża platform węglanowych, bariery węglanowej i równi platformowej (Wagner 1994). Skutkiem tego jest nie tylko zróżnicowanie ich miąższości, ale również pionowa i pozioma zmienność parametrów petrofizycznych. Strefami o najlepszych parametrach zbiornikowych są strefy barierowe, które rozwinęły się na podniesieniach podłoża. Również interesujące są - występujące na skłonach - strefy podnóża platform węglanowych, które powstały na skutek erozji barier i ich wtórnej diagenezy.

Specyficzny kształt oraz parametry petrofizyczne nasyconych stref barierowych i ich podnóża powodują, że do ich identyfikacji w zapisie sejsmicznym wykorzystywane sa zarówno elementy interpretacji strukturalnej (rozpoznanie układu strukturalnego warstw), sejsmostratygraficznej (identyfikacja facji sejsmicznych i powiązanie ich z litofacjami, co umożliwia lokalizację facji zbiornikowych) jak i złożowej (lokalizacja stref nasyconych węglowodorami na podstawie analizy sejsmicznych wskaźników węglowodorowości DHI). 
Bariera węglanowa oraz utwory osadzone na jej skłonie - to struktury organogeniczne związane genetycznie z podniesieniem podłoża, o wyraźnym reliefie, natomiast skały otaczające to osady klastyczne. Na obecność budowli węglanowych wskazuje więc przede wszystkim ułożenie refleksów, tak w obrębie samej budowli - zwykle strefa bezrefleksyjna, jak i w jej otoczeniu - wstępujące ułożenie refleksów (onlap) związanych z osadami klastycznymi strefy przedbarierowej. Osady te są bardziej podatne na kompakcję pod wpływem ciężaru warstw nadległych aniżeli sztywna budowla węglanowa. Na skutek tego: (1) interwał czasowy pomiędzy refleksami ograniczającymi rafę jest większy w strefie rafowej niż w strefie głębokowodnej, (2) natomiast w strefie basenowej interwał czasowy występujący pomiędzy refleksem spągowym rafy a horyzontem nadrafowym jest większy.

W strefie sedymentacji głębokowodnej ze stropem wapienia związany jest zwykle refleks dodatni. Natomiast w strefie rafowej porowatej i dodatkowo nasyconej, co powoduje obniżenie prędkości, można spodziewać się w stropie silnego ujemnego refleksu (bright spot), a nawet odwrócenia biegunowości refleksu spagowego (phase change). Obie te cechy zapisu wskazują na nasycenie gazem (sejsmiczne wskaźniki węglowodorowości DHI).

\section{Zloże w wapieniu cechsztyńskim Ca1}

Wapień cechsztyński Cal jest jednym z dwu perspektywicznych poziomów zbiornikowych w polskim basenie permskim. Rejonem szczególnie interesującym z punktu widzenia poszukiwań węglowodorów jest krawędź wału wolsztyńskiego, gdzie podczas pierwszej transgresji cechsztyńskiej na lokalnych paleopodniesieniach szelfu, w strefach sedymentacji barierowej tworzyły się bariery węglanowe, które stały się pułapkami, akumulującymi gaz migrujący z utworów karbonu (Wilk i in. 2004). Podłożem wapienia cechsztyńskiego są utwory karbonu (westfal) reprezentowane przez zwięzłe piaskowce szarogłazowe i arkozowe.

Gazonośność barier wapienia cechsztyńskiego potwierdzają m.in. złoża zlokalizowane w obrębie wyniesienia wolsztyńskiego. Przykładem może być złoże Kościan. Wyróżniająca się spośród stref paleogeograficznych wapienia cechsztyńskiego bariera Kościan, o miąższości od 22 do 67,5 m, zbudowana jest z organogenicznych wapieni i dolomitów. Właściwości zbiornikowe Cal zmieniają się zarówno w pionie jak i horyzontalnie. Wartości minimalne i maksymalne porowatości i przepuszczalności, np. dla otworu Kościan 10, wynoszą odpowiednio: $0,62 \%$ i $29,59 \%$ oraz $0,0 \mathrm{mD}$ i $1301,80 \mathrm{mD}$, a dla otworu Kościan 14: 1,3\% i $33,23 \%$ oraz $0,0 \mathrm{mD}$ i $761 \mathrm{mD}$ (Górski i in. 2000). Dobre warunki filtracyjne stwarzaja możliwość wykorzystania złoża jako magazynu $\mathrm{CO}_{2}$ (Uliasz-Misiak 2007). Budowle węglanowe Ca1 przykrywają, silnie zredukowane miąższościowo, poziomy anhydrytu dolnego A1D i górnego A1G, bez rozdzielającej je w strefach głębokowodnych soli najstarszej Na1. Ich miąższość nad rafą Kościan wynosi około 30-40 m. W strefach pozabarierowych 
miąższość ta wzrasta do ponad $200 \mathrm{~m}$. W strefach sedymentacji basenowej osadzała się litofacja węglanów mikrytowych, o miąższości do $5 \mathrm{~m}$, posiadających cechy skały macierzystej.

Wapień cechsztyński Ca1 charakteryzuje się prędkościami z przedziału 4000-6000 m/s oraz gęstością objętościową $\rho=2,3-2,65 \mathrm{~g} / \mathrm{cm}^{3}$. Wysokie wartości podanych parametrów są charakterystyczne dla utworów głębokowodnych, niskie dla barier, co jest związane między innymi z większą porowatością oraz nasyceniem. Wapień cechsztyński obleka warstwa anhydrytowa, która charakteryzuje się wysokimi wartościami prędkości (od 5700 do $6700 \mathrm{~m} / \mathrm{s})$ i gęstości $\left(2,9-2,95 \mathrm{~g} / \mathrm{cm}^{3}\right)$. Podścielające piaszczyste utwory karbonu mają prędkości $5500-6000 \mathrm{~m} / \mathrm{s}$ i gęstości około $2,70 \mathrm{~g} / \mathrm{cm}^{3}$.

Taki rozkład parametrów petrofizycznych kolejnych warstw powoduje, że w strefach barierowych silnymi granicami odbijającymi fale sejsmiczne są strop Ca1 (refleks ujemny bright spot) oraz strop karbonu (refleks dodatni). W strefie basenowej silną granicą sejsmiczną będzie strop kilkumetrowej warstwy anhydrytowej przykrywającej wapienie (refleks dodatni) oraz strop karbonu (refleks ujemny). Obniżenie prędkości w strefie bariery powoduje więc odwrócenie biegunowości (phase change) refleksu spagowego, co jest jednym ze wskaźników węglowodorowości (DHI).

Złoże Kościan objęte jest zdjęciem sejsmicznym Kościan-Krzywień 3D (Górski i in. 1999) oraz reinterpretacją zdjęć z tego rejonu Brońsko-Kościan 3D (Wilk i in. 2002), które wykonane zostały przez Geofizykę Torun Sp. z o.o. Przedstawiony na rysunku 1 fragment zarejestrowanego przekroju sejsmicznego pokazuje, zidentyfikowaną na podniesieniu podłoża, barierę Kościan.

W tym przypadku na jej obecność wskazuje: (1) zmniejszenie interwału czasowego w strefie bariery pomiędzy jej spagiem a horyzontem nadbarierowym w stosunku do strefy poza barierą (2) zwiększenie w strefie bariery interwału czasowego pomiędzy ograniczającymi ją refleksami, (3) zanik granic stropowych Na1 i A1D na granicy bariery, co jest związane z brakiem w strefie nadbarierowej utworów soli najstarszej. Natomiast o nasyceniu świadczy: (1) silny ujemny refleks w stropie bariery (brihgt spot) oraz (2) obserwowana na granicy bariery zmiana biegunowości spagowego refleksu cechsztynu (Zsp) z ujemnej na dodatnią (phase change).

Przestrzenny zasięg zidentyfikowanej na przekrojach sejsmicznych bariery Kościan oraz występujące w sąsiedztwie, także w strefie barierowej złoże Brońsko widoczny jest na mapach wykonanych na bazie różnych sejsmicznych wskaźników identyfikacji barier węglanowych. Świetnym przykładem jest mapa ekstrakcji amplitudy obliczonej dla spągowej granicy cechsztynu Zsp, na której lokalizację barier identyfikuje zmiana znaku amplitudy. Amplitudy dodatnie świadczą o obecności w poziomie wapienia cechsztyńskiego porowatej i nasyconej węglowodorami facji barierowej, ujemne wskazują natomiast na występowanie mikrytowych facji zbitych węglanów, nieperspektywiczny z punktu widzenia poszukiwań naftowych. Strefy anomalne (rys. 2) o dodatnich amplitudach uwidaczniaja palczasty zasięg obu obiektów, objętych zdjęciem sejsmicznym - bariery Kościan oraz bariery Brońsko. 


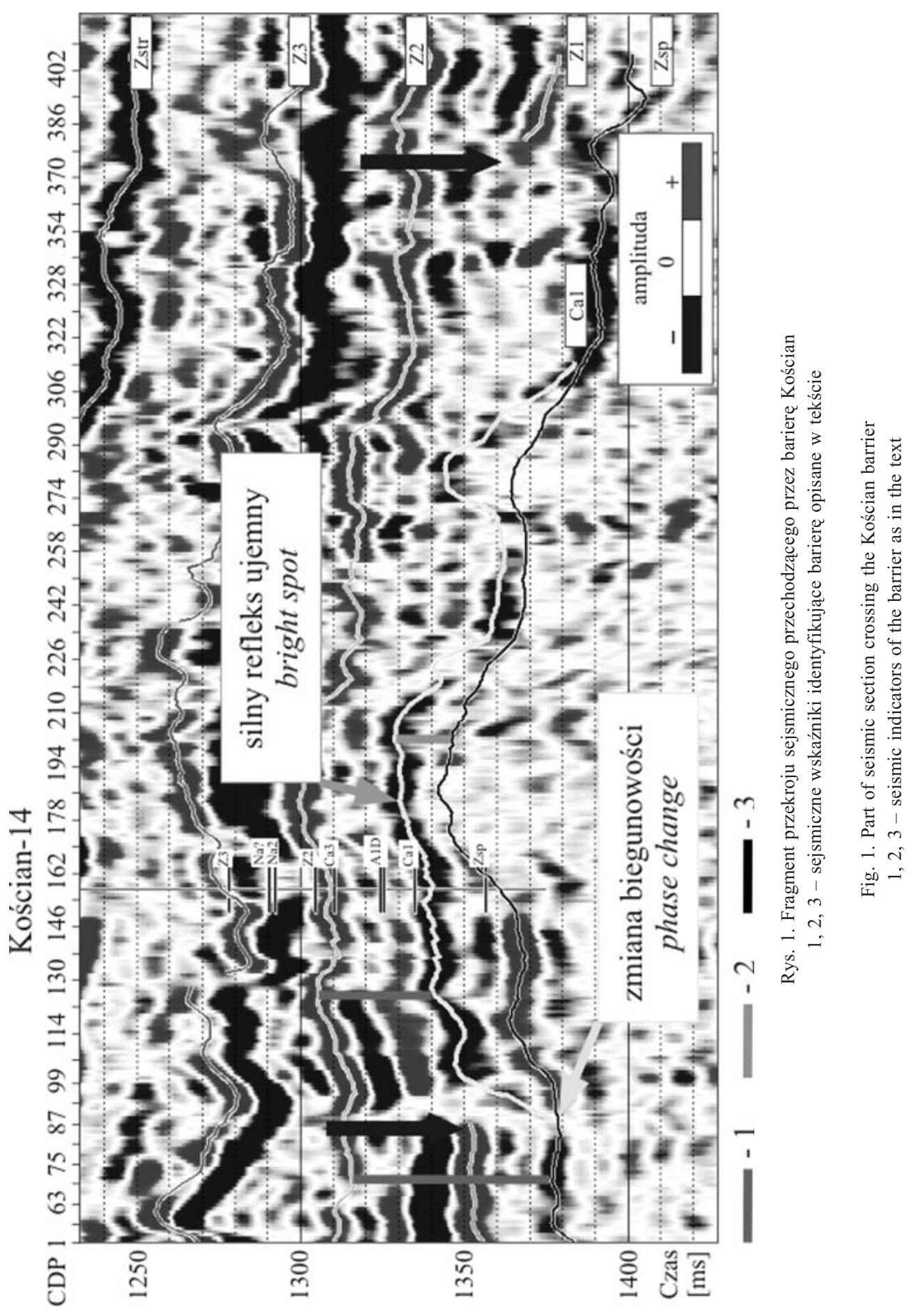




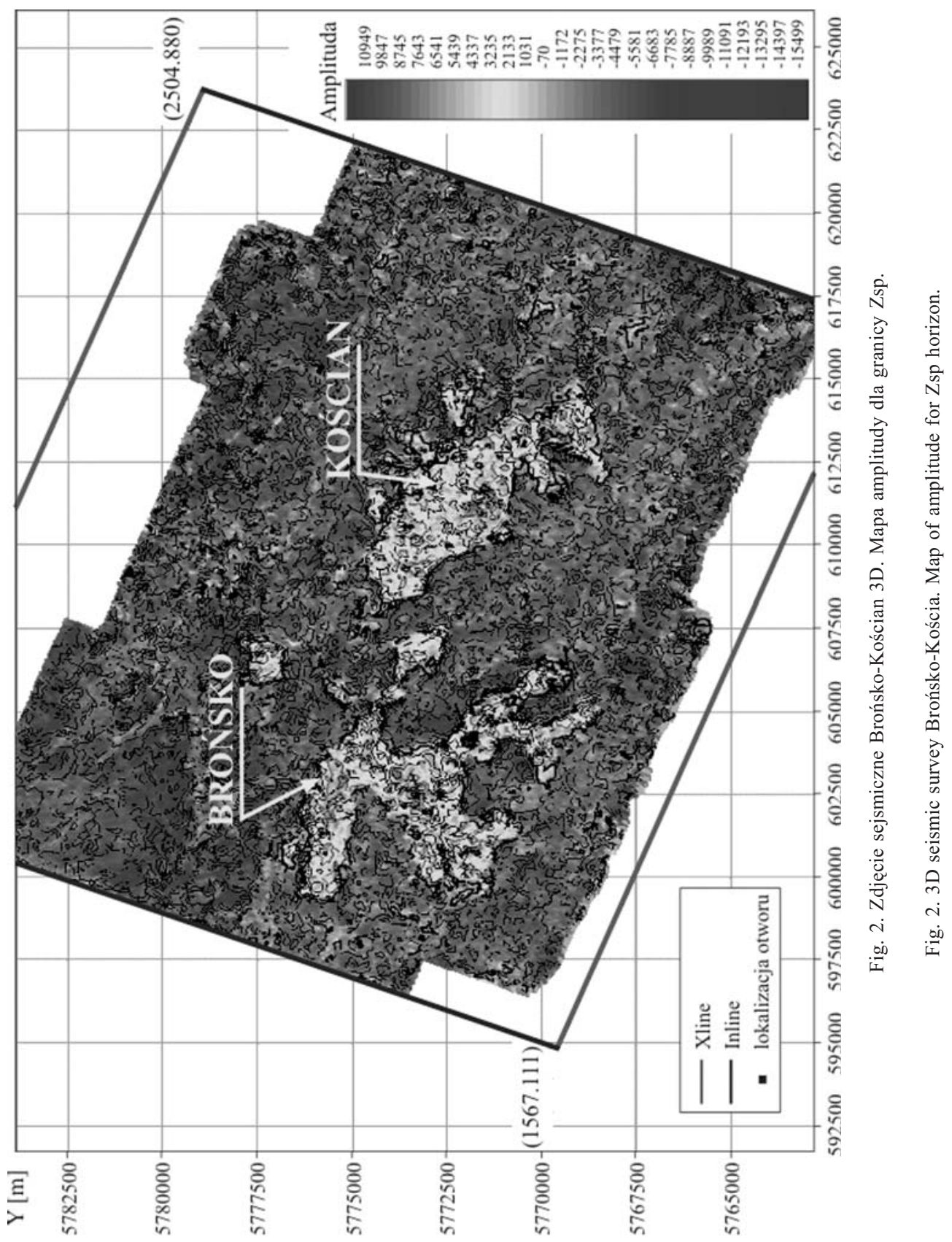




\section{Zloże w dolomicie głównym Ca2}

Głównym poziomem złożowym w polskim basenie cechsztyńskim jest dolomit główny (Ca2). Rozpoczyna on sedymentację cyklotemu PZ2. Zmienna morfologia dna, będąca wynikiem sedymentacji wcześniejszego cyklotemu PZ1, miała dominujący wpływ na sposób wykształcenia osadów dolomitu głównego (Wagner 2000; Wagner i in. 2000). Jedno z największych złóż w Polsce - złoże Barnówko-Mostno-Buszewo (BMB) - jest wynikiem sedymentacji węglanów w strefie barierowej. O sejsmicznym odwzorowaniu złóż tego typu była już mowa w poprzednim rozdziale. Ze strefą skłonu platformy związane jest natomiast złoże Lubiatów, które zlokalizowane jest w obrębie bloku Gorzowa.

W strefie złoża Lubiatów anhydryt górny (A1G) podścielający dolomit główny ma miazżzzości około $45 \mathrm{~m}$, pod którym z kolei zalega warstwa soli najstarszej (Na1). Występujący u podnóża platformy dolomit główny charakteryzuje się naprzemiennym zaleganiem wapieni i dolomitów, z przewagą tych ostatnich. W kolejnych otworach Ca2 osiaga miąższości: Lubiatów-2 - 48 m, Lubiatów-1 - 56 m, Lubiatów-4 - 45,5 m. Nad węglanowymi osadami Ca2 występuje anhydryt podstawowy (A2), wykształcony jako anhydryt krystaliczny, o miąższościach 4-6,5 m. Powyżej w profilu występuje sól starsza (Na2), której miąższość przekracza $150 \mathrm{~m}$. W strefach sedymentacji głębokowodnej dolomit główny, wykształcony w facji wapieni silnie zailonych, ma jedynie kilkumetrowe miąższości (Papiernik i in. 2012).

Utwory dolomitu głównego w strefie podnóża platformy węglanowej (otwór Lubiatów-1) charakteryzują się, w zależności od wykształcenia, porowatością efektywną $\Phi$ od 10 do $25 \%$, gęstością objętościową $\rho$ od 2,17 do $2,46 \mathrm{~g} / \mathrm{cm}^{3}$ oraz prędkością propagacji fal $\mathrm{Vp} \approx 4500 \mathrm{~m} / \mathrm{s}$. W strefie głębokowodnej (otwór Leszczyny-1) parametry te wynoszą odpowiednio: $\Phi \approx 6 \%, \rho \approx 2,6 \mathrm{~g} / \mathrm{cm}^{3}$ oraz $\mathrm{Vp} \approx 5400 \mathrm{~m} / \mathrm{s}$. Dla obu otworów parametry petrofizyczne, zarówno warstw bezpośredniego nadkładu (A2) jak i podłoża (A1G) mają wartości: $\rho \approx 2,9 \mathrm{~g} / \mathrm{cm}^{3}, \mathrm{Vp} \approx 5900 \mathrm{~m} / \mathrm{s}$ (Papiernik i in. 2012).

Korelacja zapisu sejsmicznego z parametrami petrofizycznymi wyznaczonymi dla otworu Lubiatów-1 pozwala na powiązanie: (1) dodatniego refleksu z warstwą anhydrytu podstawowego A2, (2) silnego ujemnego refleksu (bright spot) ze stropem dolomitu głównego (obniżenie w strefie złożowej prędkości i gęstości utworów Ca2), (3) silnego refleksu dodatniego ze stropem, podścielającego dolomit, anhydrytu górnego A1G o wysokiej prędkości, (4) kolejnego silnego refleksu ujemnego z granicą A1G/Na1.

W strefie głębokowodnej, gdzie zarówno A2 jak i Ca2 mają małe miąższości, odbicia od stropu A2, stropu Ca2 oraz stropu A1G interferują, tworząc jeden dodatni sygnał o dużej amplitudzie. Zdjęcie sejsmiczne 3D Międzychód-Sieraków (2002) oraz jego reinterpretacja (Trela i in. 2009) wykonane przez Geofizykę Toruń Sp. z o.o. objęło swym zasięgiem złoże Lubiatów, zlokalizowane na obszarze pótwyspu Grotowa (patrz mapa paleograficzna $\mathrm{Ca} 2$ - Wagner i in. 2000). Fragment profilu arbitralnego przechodzacy przez złoże Lubiatów (otwory Lubiatów-2, Lubiatów-1 i Lubiatów-4) pokazany jest na rysunku 3. 


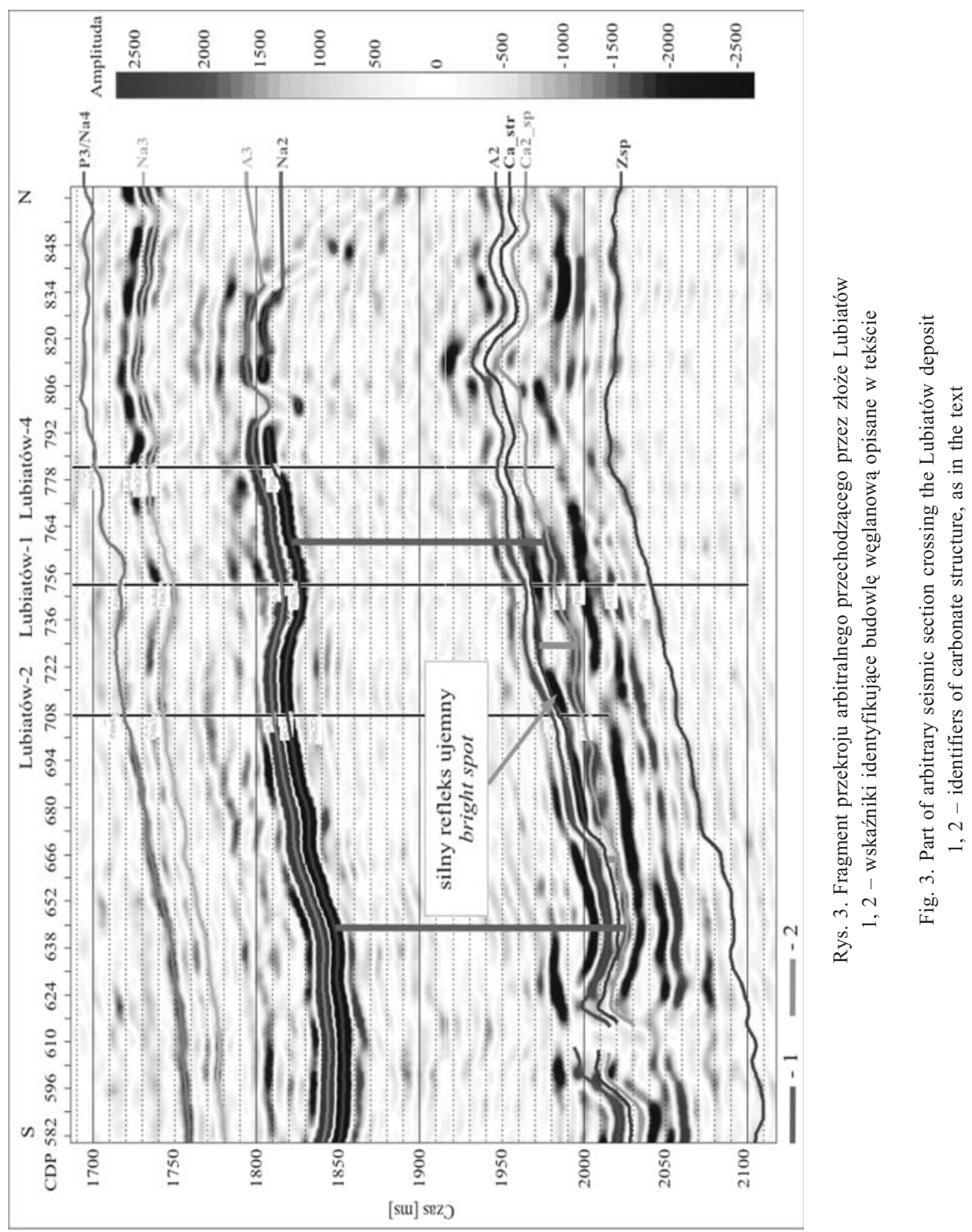




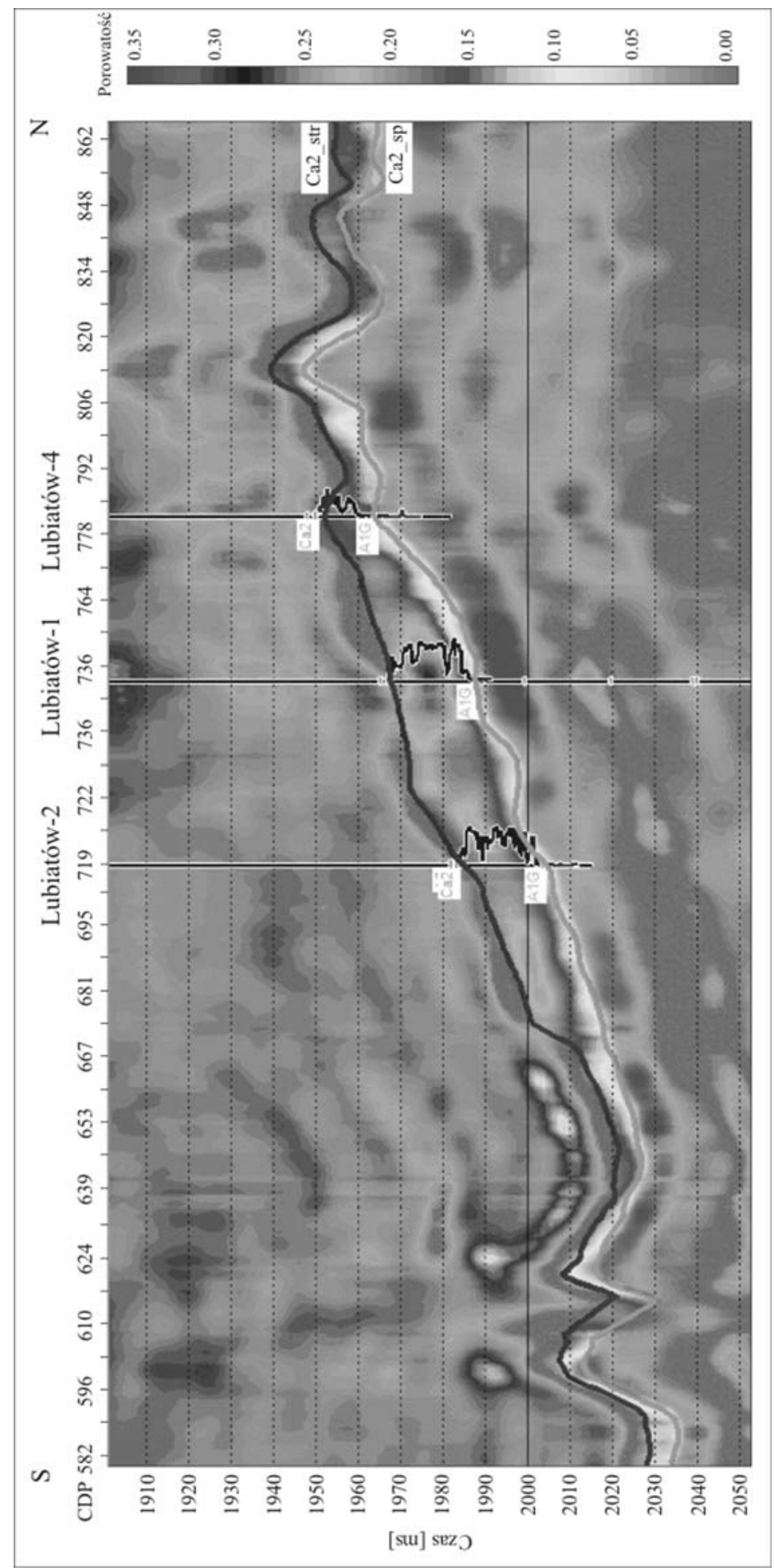

可 
Na obecność budowli węglanowej w dolomicie głównym wskazują: (1) interwał czasowy pomiędzy spagiem $\mathrm{Ca} 2$ a refleksem nadrafowym jest większy w strefie głębokowodnej niż w strefie budowli węglanowej (2) interwał czasowy pomiędzy refleksami ograniczającymi utwory Ca2 jest większy w strefie podnóża platformy aniżeli w strefie głębokowodnej; (3) pojawienie się w stropie Ca2 silnego refleksu ujemnego - bright spotu, odpowiadającego stropowi porowatego i nasyconego dolomitu.

Obliczony w systemie Hampson-Russell, oparty na prędkościach inwersyjnych i danych otworowych, rozkład porowatości dolomitu głównego wzdłuż horyzontu Ca2 (rys. 4) potwierdza lokalizację strefy nasyconej. Dolomit główny w obszarze podnóża stoku platformy węglanowej (złoże Lubiatów) wykazuje wysokie wartości porowatości inwersyjnej. W strefie lokalizacji otworów Lubiatów-1 i Lubiatów-2 dochodzą nawet do $25 \%$. W strefie głębokowodnej porowatości są rzędu kilku procent (Pietsch, Niepsuj 2012).

\section{Strefa potencjalnej akumulacji gazu na obszarze KGHM ZG Rudna}

Zakład Górniczy Rudna KGHM Polska Miedź S.A. prowadzi roboty górnicze związane z udostępnieniem nowej partii złoża w rejonie Obszaru Górniczego Głogów Głęboki Przemysłowy (Kaczmarek, Rożek 2008). Na poziomie około 1190 m p.p.t. wykonywane są wiązki chodników rozcinające złoże i ze względu na małą miąższość łupka miedzionośnego chodniki prowadzone są też w dolomitach wapienia cechsztyńskiego Ca1. Miąższość dolomitu wynosi w rejonie robót około $11 \mathrm{~m}$.

We wrześniu 2009 roku, prowadząc wiązkę chodników 169 (rys. 5), kopalnia Rudna natrafiła w chodniku T169a na „pułapkę gazową” o niewielkiej kubaturze, lecz dużym ciśnieniu. Pobrane próby gazowe z miejsca występowania „pułapki gazowej” jak i z otworu badawczego Jm20H5 poddane zostały badaniom geochemicznym pod kątem oznaczenia składu cząsteczkowego i izotopowego. Wykonane badania wskazują, że jest on genetycznie najbardziej zbliżony do gazu ziemnego akumulowanego w złożach znajdujących się w skałach zbiornikowych wapienia cechsztyńskiego i czerwonego spagowca na Niżu Polskim, w tym na obszarze przedsudeckim, a więc w odległości 30-40 km od obszaru górniczego ZG Rudna. Gaz ten pochodzi z substancji organicznej zawartej w utworach karbonu i czę́siowo dewonu (Kotarba 2010).

W omawianym rejonie występują liczne uskoki. Tak więc można przyjąć tezę, że gaz mógł dopłynąc piaskowcami czerwonego spagowca, a następnie migrował systemem uskoków na poziomie Cal i wypełnił szczelinowe partie dolomitu.

W celu kontroli gazonasycenia wapienia cechsztyńskiego (dolomit) z poziomu chodników w Cal wywiercono otwory badawcze. W trzech z wykonanych odwiertów (rys. 5) stwierdzono objawy gazowe. W otworze Jm20H5 uzyskano wypływ gazu (głównie azotu) o ciśnieniu 27 at i łącznej objętości $6956 \mathrm{~m}^{3}$, przy zawartości metanu $2,6 \%$, natomiast w otworze Jm20H8 pojawił się gaz o ciśnieniu 60 at i łącznej objętości aż $28634 \mathrm{~m}^{3}$ przy zawartości metanu 5,1\%, a w otworze Jm20H10 o ciśnieniu 38 at i łącznej objętości $2088 \mathrm{~m}^{3}$ 


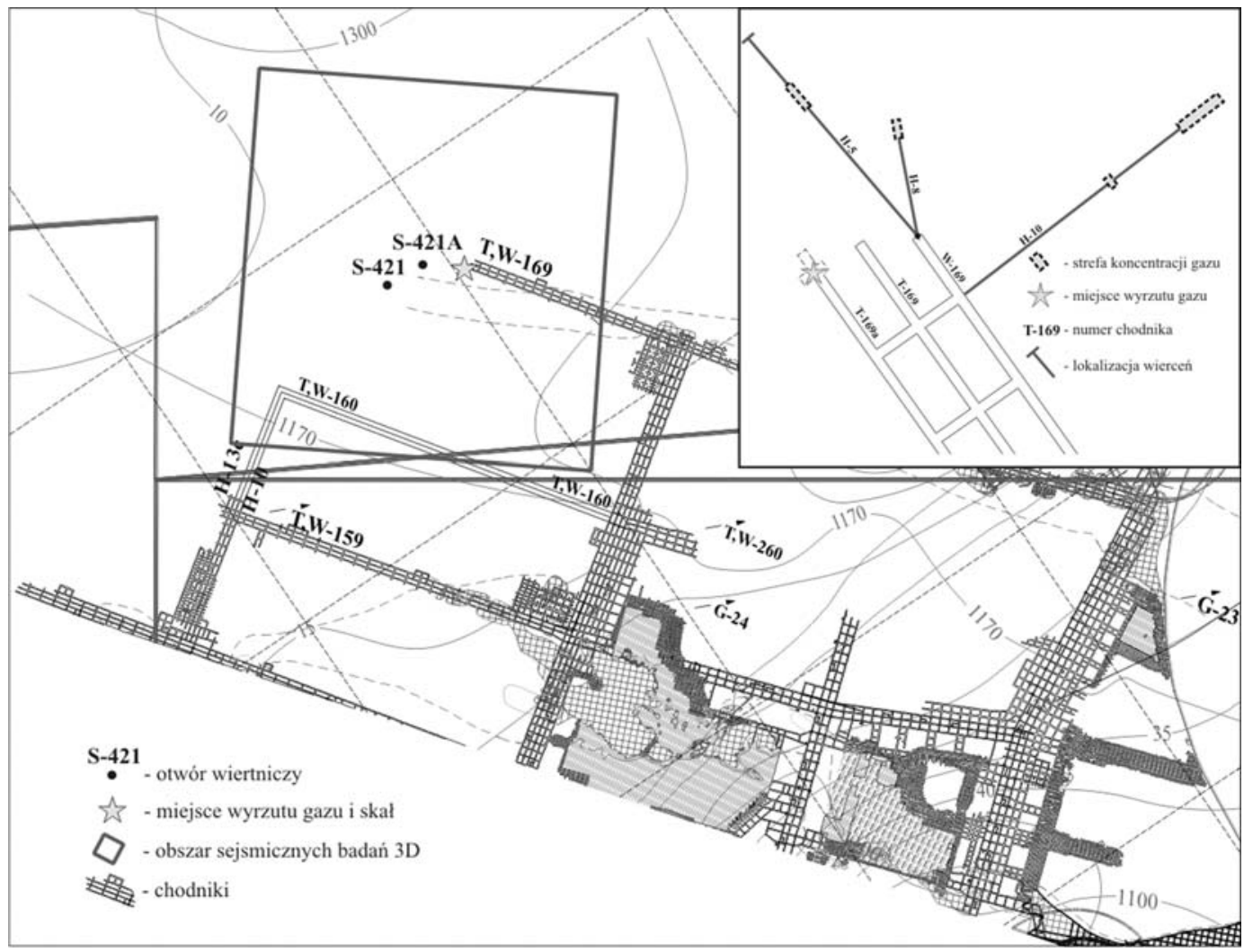

Rys. 5. Lokalizacja badań sejsmicznych 3D na tle sieci wyrobisk górniczych ZG Rudna

Fig. 5. Location of 3D seismic survey at the background of Rudna mine drifts

przy zawartości metanu 5,25\% (KGHM POLSKA MIEDŹ S.A. OZG Rudna 2010). Wyniki wierceń wskazują na nieregularne występowanie stref koncentracji gazu wokół miejsca „pierwszej kawerny gazowej” w chodniku T-169a.

Wykonane, ponad strefą wyrzutu, sejsmiczne badania 3D (rys. 5) dostarczyły informacji o budowie górotworu (Geofizyka Kraków Sp. z o.o. 2010a). Opierając się na uzyskanych danych sejsmicznych obliczono rozkłady atrybutów sygnału sejsmicznego i na ich podstawie podjęto próbę identyfikacji stref anomalnych na poziomie Zsp (granica cechsztyn/czerwony spagowiec). Założono, że (1) strefy te mogą korelować z miejscami podwyższonej porowatości, szczelinowatości dolomitów i mogą być potencjalnymi strefami koncentracji gazu, (2) uskoki stanowią drogi migracji gazu do stref rozluźnionych w dolomitach Ca1.

W celu dowiązania zapisu sejsmicznego do profilu litostratygraficznego, na podstawie danych geofizyki otworowej tj. krzywych prędkości i gęstości (Geofizyka Kraków Sp. z o.o. 2010b) oraz ekstrahowanego z zapisu sygnału sejsmicznego o częstotliwości $25 \mathrm{~Hz}$ obliczono sejsmogramy syntetyczne dla modelu profilu otworu S-421A zlokalizowanego w odległości $250 \mathrm{~m}$ od miejsca występowania ,,pułapki gazowej”, w centrum obszaru zdjęcia 3D 
(rys. 5). Niskie częstotliwości powodują, że sejsmiczny zapis utworów cechsztynu nie jest jednoznaczny. Wyraźnie widać to na fragmencie sejsmogramu syntetycznego, obejmującym utwory cechsztynu (rys. 6), gdzie dla sygnału o częstotliwościach rzędu $25 \mathrm{~Hz}$ cechsztyn jest ośrodkiem cienkowarstwowym. Jedynie odbicia od stropu soli najstarszej Na1 (silny sygnał ujemny) oraz stropu anhydrytu dolnego A1D (silny refleks dodatni) dowiązane są w sposób jednoznaczny. Natomiast sygnały, które można wiązać ze stropem (Ztop) jak i spagiem cechsztynu (Zsp) są sygnałami interferencyjnymi. Szczególnie ważny jest refleks Zsp, który obejmuje warstwę dolomitu Cal, łupka miedzionośnego ŁM oraz białego piaskowca BP. Nieznaczny wzrost prędkości w stropie dolomitu niwelowany jest spadkiem gęstości, tak że współczynnik odbicia ma prawie zerową wartość (rys. 6). W tej sytuacji granica anhydryt/dolomit nie wpływa na kształtowanie sygnału i w związku z tym sejsmiczna granica Zsp jednoznacznie związana jest z silną granicą odbijającą, występującą pomiędzy dolomitem Ca1 a piaskowcami białego spagowca (BP). Jego amplituda jest zależna nie tylko od parametrów petrofizycznych wymienionych powyżej warstw, ale także od parametrów stropowego anhydrytu dolnego (A1D) i spągowego czerwonego spagowca (CS). Analizując obliczony sejsmogram syntetyczny oraz zestawienie prędkości i gęstości (rys. 6) należy stwierdzić, że refleks wiązany z granicą cechsztyn/czerwony spagowiec ma dużą ujemną amplitudę.

Miejsce wyrzutu gazu, zaznaczone na mapie średnich kwadratowych amplitud (RMS) sygnału odbitego od granicy sejsmicznej Zsp (rys. 7), zlokalizowane jest w strefie, która w obrazie sejsmicznym posiada znamiona uskoku (interpretowany uskok A). Jest on sprzężony uskokiem 2, będącym południowym ograniczeniem rowu biegnącego z NW na SE. Założono, że stanowił on drogę migracji gazu karbońskiego do pułapki zbudowanej z porowato-szczelinowych utworów Ca1. Rejestrowane w tej strefie pole falowe obrazuje sejsmiczny przekrój arbitralny V-V (rys. 8a). Na obecność ewentualnego uskoku normalnego wskazują: (1) wyraźne przerwanie ciagłości horyzontu Zsp, (2) przemieszczenie skrzydła zrzuconego o około $15 \mathrm{~ms}$ (ok. $22 \mathrm{~m}$ ), (3) zaburzenie w ciągłości horyzontu A1D (strop anhydrytu dolnego), (4) obecność fal dyfrakcyjnych oraz (5) obniżenie w strefie zrzuconej amplitudy refleksu Zsp.

Na rysunku 8 b przedstawiony jest sejsmiczny przekrój arbitralny G-G', którego przebieg pokrywa się z linią wiercenia Jm20H5 (rys. 7). Analiza refleksu Zsp na odcinku pokrywającym się z przebiegiem wiercenia pokazuje zmniejszanie się jego amplitudy, które ciagnie się aż do strefy przypuszczalnego uskoku A. Strefa ta mogła gromadzić gaz migrujący z utworów czerwonego spagowca. Wykonane z chodnika W169, w celu wyjaśnienia przyczyny wyrzutu, wiercenie Jm20H5 nie potwierdziło obecności uskoku. Tak więc widoczne $\mathrm{w}$ zapisie sejsmicznym zaburzenie może być jedynie korelowane $\mathrm{z}$ występowaniem strefy spękanej dolomitu Ca2.

Jak wykazały wykonane modelowania (Dec i in. 2011), amplituda refleksu wiązanego z granicą dolomit/piaskowiec (Zsp) osiagga maksymalną ujemną wartość, gdy dolomit charakteryzuje się dobrymi właściwościami sprężystymi. Natomiast osłabienie dolomitu, wywołane np. wzrostem porowatości i szczelinowatości, prowadzi do zbliżenia wartości 


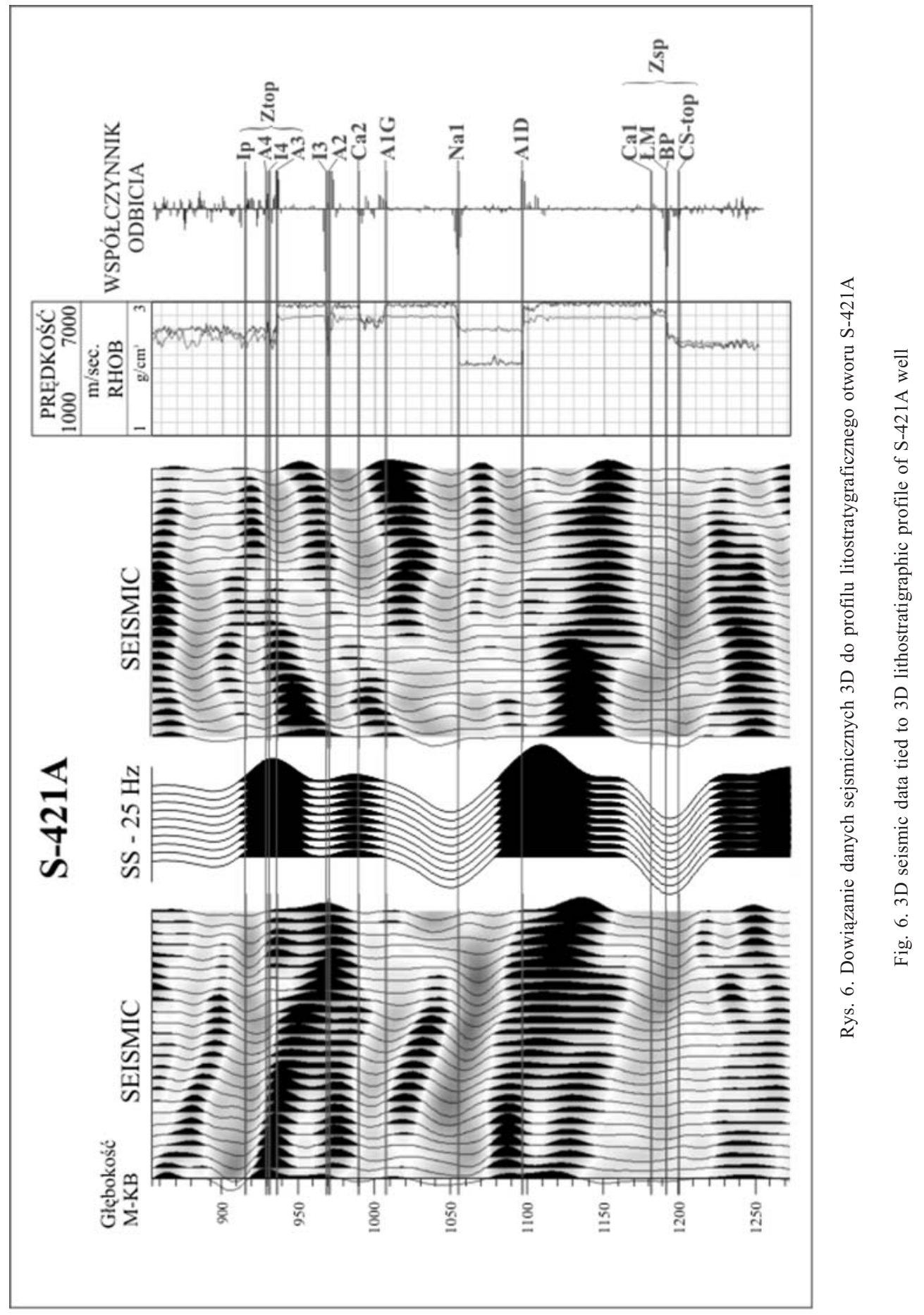


parametrów petrofizycznych Cal do parametrów BP, co powoduje zmniejszenie ujemnej amplitudy. Dodatkowym czynnikiem obniżającym amplitudę może być nasycenie gazem (obniżenie prędkość propagacji fal sejsmicznych). Powierzchniowy rozkład amplitudy RMS refleksu Zsp pokazany jest na rysunku 7. Jak wynika z analizy powyższej mapy końcowa część wiercenia prowadzona była w strefie zmniejszenia amplitudy odbicia od granicy Zsp, do prawie zerowej wartości, co wskazuje na obniżenie właściwości sprężystych dolomitu. W wierceniu Jm20H5, pomiędzy 92 a 98 m uzyskano dopływ gazu o ciśnieniu 27 at, którego łączna objętość wyniosła około $7000 \mathrm{~m}^{3}$. Wynik wiercenia weryfikuje więc obecność strefy o zwiększonej porowatości i szczelinowatości oraz nasycenie gazem.

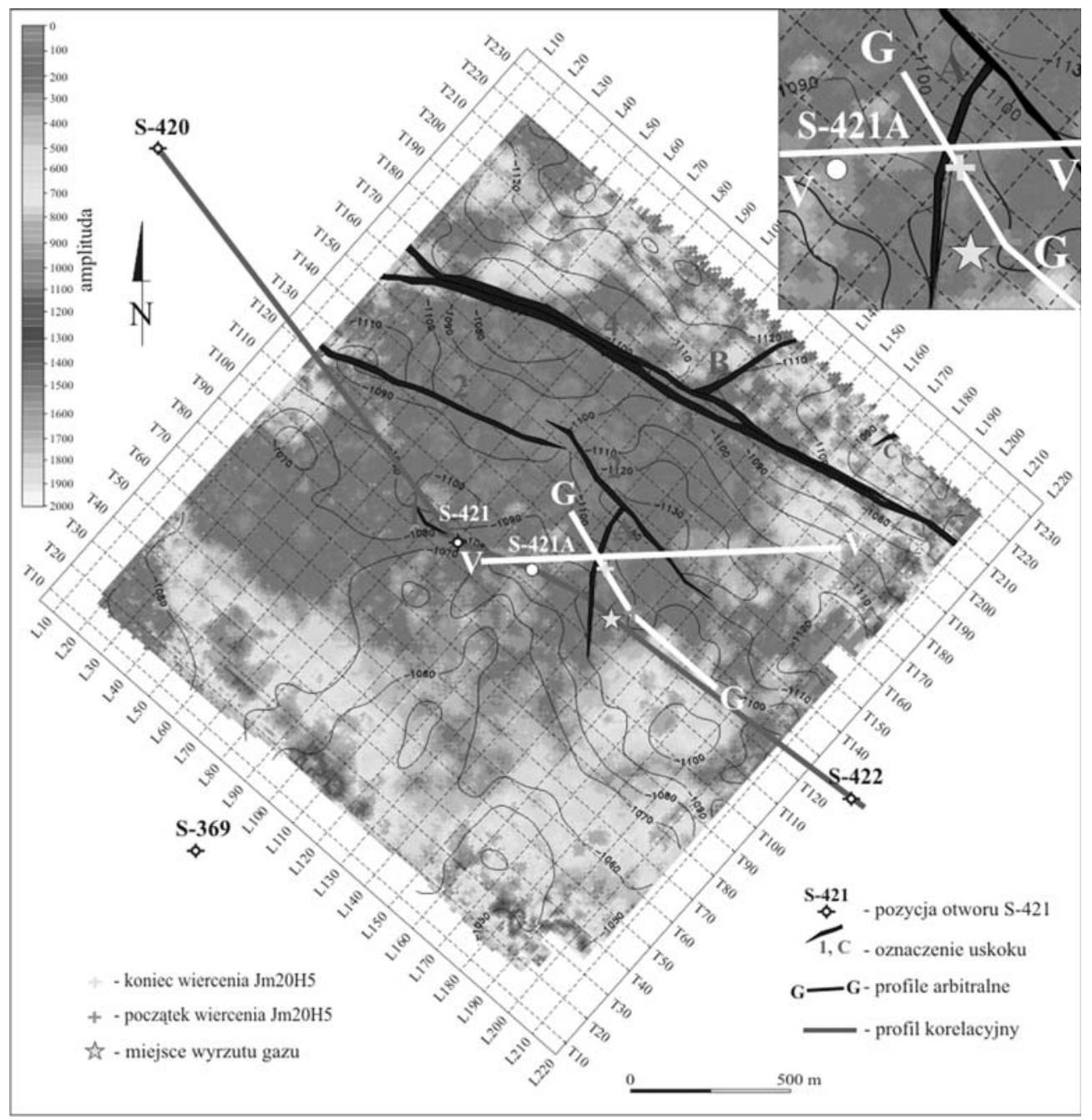

Rys. 7. Mapa amplitud RMS dla horyzontu Zsp

Fig. 7. Map of RMS amplitudes for horizon Zsp 

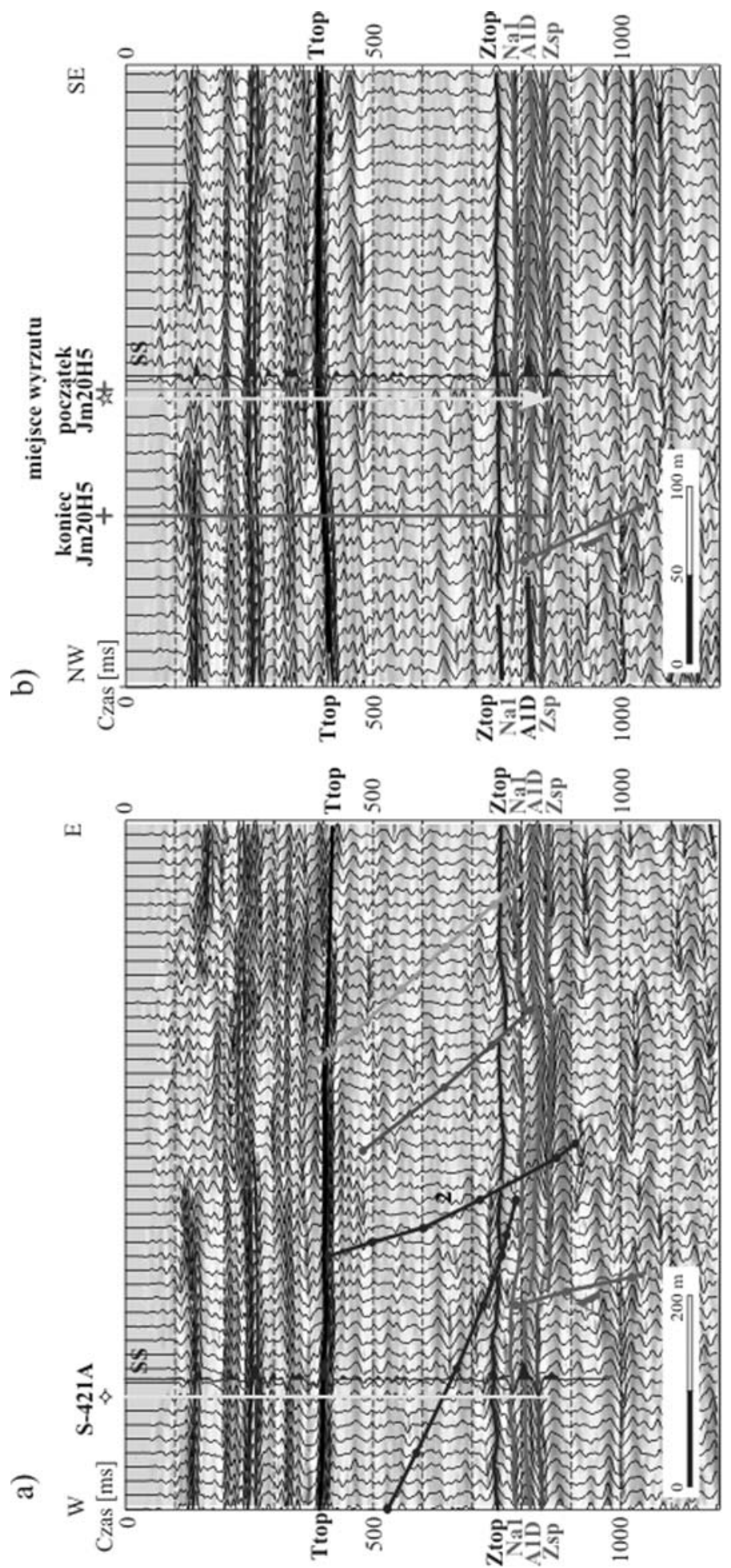
Podsumowując wynik badań sejsmicznych można przyjąć, że sejsmicznym wskaźnikiem identyfikacji stref o obniżonych parametrach sprężystych i ewentualnym nasyceniu gazem dolomitu w poziomie wapienia cechsztyńskiego Ca1 na obszarze ZG Rudna jest zerowa lub prawie zerowa wartość amplitudy refleksu, wiązanego z granicą cechsztyn/ /czerwony spagowiec (Zsp).

\section{Dyskusja wyników}

Różna budowa geologiczna analizowanych w artykule stref nasyconych gazem, a co za tym idzie stref o różnych parametrach petrofizycznych powoduje, że i sejsmiczny obraz tych stref jest zdecydowanie różny.

Złoże Kościan zlokalizowane jest w obrębie bariery węglanowej wapienia cechsztyńskiego (Ca1), podłożem są piaszczyste utwory karbonu (C), a w nadkładzie zalega warstwa anhydrytu (A1D + A1G). Rozkład impedancji akustycznej $(\mathrm{Vp} \cdot \rho)$ w modelu sejsmogeologicznym tej strefy zawiera kolejno: (1) warstwę A1 o najwyższej impedancji, (2) barierę Ca2 o najniższej impedancji oraz (3) piaszczyste utwory karbonu o impedancji pośredniej. Taki rozkład parametrów petrofizycznych powoduje, że w stropie bariery rejestrowany będzie ujemny refleks (bright spot), a w stropie podłoża dodatni. W strefie basenowej rozkład impedancji jest inny: (1) anhydryt A1D o wysokiej impedancji, (2) cienka warstwa dolomitu o impedancji pośredniej oraz (3) utwory karbonu (C) o najniższej impedancji. Obraz falowy będą więc budowały refleks dodatni w stropie A1D (granica Na1/A1D) oraz refleks ujemny w spagu cechsztynu. Obniżenie impedancji w strefie bariery powoduje więc odwrócenie biegunowości (phase change) refleksu spagowego cechsztynu (Zsp), co jest w tym przypadku głównym wskaźnikiem nasycenia. Dodatkowo na obecność bariery wskazują kryteria miąższościowe, omówione w tekście.

Złoże Lubiatów związane jest ze skłonem platformy węglanowej dolomitu głównego Ca2. Warstwami podścielającymi są anhydryt górny A1G i leżąca pod nim sól najstarsza (Na1), a warstwami nadległymi anhydryt podstawowy A2 oraz sól starsza Na2. Dla takiej budowy geologicznej rozkład impedancji akustycznej jest inny aniżeli dla bariery Kościana: (1) warstwa anhydrytu A2 o impedancji najwyższej, (2) dolomit główny Ca2 o impedancji najniższej oraz (3) anhydryt górny (A1G) o impedancji zbliżonej do impedancji A2. Dla takiego rozkładu impedancji silny, dodatni refleks stropowy będzie odpowiadał granicy Na2/A2, silny refleks ujemny (bright spot) obrazuje strop strefy nasyconej Ca2, kolejny refleks dodatni strop anhydrytu górnego (A1G), a kolejny refleks ujemny odwzorowuje granicę A1G/Na1. W facji basenowej zarówno anhydryt podstawowy A2 jak i dolomit Ca2 mają kilkumetrowe miąższości, co powoduje, że odbicia od granic Na2/A2, A2/Ca2 oraz Ca2/A1G interferują, tworząc jeden silny refleks dodatni. Przy omówionym powyżej modelu sejsmogeologicznym na obecność strefy nasyconej wskazywać będzie przede wszystkim bright spot, który odwzorowuje strop strefy nasyconej. Kryteria miąższościowe są także i w tym przypadku wykorzystywane do identyfikacji budowli węglanowych powstałych na skłonach platform. 
Obecność nasyconej gazem strefy w dolomicie Ca1 w ZG Rudna KGHM ujawnił w 2009 r. wyrzut do chodnika rozdrobnionego materiału skalnego oraz próby gazowe z wykonanych przez kopalnie odwiertów badawczych. Utwory budujące złoże miedzi: dolomit Ca1, łupek miedzionośny ŁM oraz piaskowce białego spagowca BP mają małe miąższości. Kompleks ten przykrywa warstwa anhydrytu dolnego A1D i soli najstarszej Na1. W podłożu zalegają utwory czerwonego spagowca CS. Sejsmiczne odwzorowanie tej strefy to: (1) strop Na1 - refleks ujemny, (2) strop A1D - refleks dodatni oraz (3) zinterferowany, ujemny refleks Zsp, który obejmuje warstwę dolomitu Ca1, łupka miedzionośnego ŁM oraz piaskowców białego spagowca BP. Rozkład impedancji pokazuje, że amplituda tego refleksu, kształtowana przez granicę Ca1/BP, ma maksymalną wartość ujemną, gdy dolomit charakteryzuje się dobrymi właściwościami sprężystymi. Natomiast osłabienie dolomitu, wywołane np. wzrostem porowatości i szczelinowatości oraz nasyceniem, prowadzi do zbliżenia wartości parametrów petrofizycznych Ca1 do parametrów BP, co powoduje zmniejszenie ujemnej amplitudy. Sejsmicznym wskaźnikiem identyfikacji stref porowato-szczelinowatych dolomitu w poziomie wapienia cechsztyńskiego Ca1 (i ewentualnie nasyconych gazem) na obszarze ZG Rudna jest więc zerowa lub prawie zerowa wartość amplitudy refleksu, wiązanego z granicą cechsztyn/czerwony spagowiec (Zsp).

Przedstawione w artykule przykłady pokazują możliwości sejsmicznej identyfikacji stref nasycenia gazem w węglanowych utworach cechsztynu. Różne sejsmiczne kryteria identyfikacji stref nasyconych są wynikiem różnego rozkładu parametrów petrofizyczych występujących przy nasyceniu gazem węglanów strefy barierowej, strefy podnóża platformy węglanowej i strefy basenowej o słabych parametrach sprężystych. Opracowanych kryteriów nie można jednak uznać za uniwersalne. Zmienność budowy geologicznej jest bowiem tak duża, że przy interpretacji złożowej danych sejsmicznych zarejestrowanych w różnych częściach basenu cechsztyńskiego koniecznym jest każdorazowe opracowanie kryteriów lokalnych. Metodą wspomagającą opracowanie kryteriów są modelowania sejsmiczne 1D (sejsmogramy syntetyczne) oraz 2D (Dec i in. 2011; Pietsch i in. 2007; Pietsch, Niepsuj 2012).

\section{LITERATURA}

Dec i in. 2011 - Dec J., Piets ch K., Marzec P., 2011 - Application of seismic methods to identify potential gas concentration zones at the Zechstein limestone level in the "Rudna" mining area. Annales Societatis Geologorum Poloniae, vol. 81: 63-78.

Geofizyka Kraków Sp. z o.o., 2010a - Dokumentacja wyników badań sejsmicznych, temat - sejsmiczne badania powierzchniowe 3D Duża Wólka. Archiwum Geofizyka Kraków Sp. z o.o.

Geofizyka Kraków Sp. z o.o., 2010b - Zestawienie wyników przetwarzania i transformacji danych geofizyki wiertniczej do standardów sejsmicznych, temat - Duża Wólka 3D. Archiwum Geofizyka Kraków Sp. z o.o.

Górski i in. 2000 - Górs ki M., G i ers zew s ka D., Król E., U rb ań s k a H., W ilk W., 2000 - Interpretacja litofacjalna danych sejsmiki 3D kluczem do sukcesu w detekcji ciał rafowych w poziomie wapienia cechsztyńskiego w basenie permskim (na przykładzie rafy Kościan). Przegląd Geologiczny 48, 2, 137-150. 
Górski i in. 1999 - Górs ki M., Ło mn icki R., B u k ow i c ki J., 1999 - Opracowanie badań sejsmicznych 3D rejon: Kościan-Krzywiń. Archiwum Geofizyka Toruń Sp. z o.o.

Kaczmarek W., Rożek R., 2008 - Budowa geologiczna i zagospodarowanie złoża Głogów Głęboki Przemysłowy (KGHM Polska Miedź S.A.). Gospodarka Surowcami Mineralnymi, t. 24, z. 4/4, s. $129-141$.

KGHM Polska Miedź S.A. OZG „Rudna”, 2010 - Aktualny stan rozpoznania stanu zagrożenia gazowego w chodnikach T-169 i W-169. Materiały WUG. Katowice.

Kotarba M., 2010 - Badania geochemiczne i interpretacja genetyczna gazu ziemnego z otworu badawczego JM20H5. Dokumentacja Towarzystwa Badania Przemian Środowiska „Geosfera”. Kraków.

Papiernik i in. 2012 - Papiernik B., Machowski G., Pasternacki A., Krakowska P., Maruta M., 2012 - Modele strukturalny i facjalno-parametryczny rejonu Gorzów Wielkopolski - Pniewy. [W:] Semyrka R. (kier) Facjalno-strukturalne uwarunkowania akumulacji węglowodorów dolomitu głównego (Ca2) w granicznej strefie platformy węglanowej w obszarze Gorzów-Pniewy. Grant KBN N N525 348538 , AGH 18.18.140.878. Archiwum Katedry Surowców Energetycznych GiOŚ AGH, Kraków.

Pietsch i in. 2007 - Pietsch K., Marzec P., Kobylarski M., Danek T., Leśniak A., Tatarata A., Gruszczyk E., 2007 - Identification of Seismic Anomalies Caused by Gas Saturation on the Basis of Theoretical P and PS Wavefield - Carpathian Foredeep, SE Poland. Acta Geophysica vol. 55, no. 2, p. 191-205.

Pietsch i in. 2012 - Piets ch K., Marzec P., Niepsuj M., Krzywiec P., 2012 - The influence of seismic velocity distribution on the seismic imaging of the sub-Zechstein strata boundaries in areas affected by salt tectonics. Annales Societatis Geologorum Poloniae. Złożone do druku.

Pietsch K., Niepsuj M., 2012 - Estymacja wybranych parametrów petrofizycznych w oparciu o atrybuty sejsmiczne oraz dane geofizyki otworowej. [W:] Semyrka R. (kier) Facjalno-strukturalne uwarunkowania akumulacji węglowodorów dolomitu głównego (Ca2) w granicznej strefie platformy węglanowej w obszarze Gorzów - Pniewy. Grant KBN N N525 348538, AGH 18.18.140.878. Archiwum Katedry Surowców Energetycznych WGGiOŚ AGH, Kraków.

Pikulski L., 2004 - Analiza paleograficzna utworów dolomitu głównego (Ca2) w rejonie Lubiatów-Międzychód-Grotów w aspekcie poszukiwania złóż”, Nafta-Gaz, 09.

Pilecki i in. 2012 - Pilecki Z., Laskowski M., Czarny R., Wróbel J., Hryciuk A., Koziarz E., Krawie c K., Pilecka E., 2012 - Capabilities of identyfication of weak zones in structure of the copper ore deposit using seismic tomography. Proc II nd Int. Copper Ore Min. Cong., Suplement. Lubin, 16-18 July 2012, 1-13 (in Polish)

Trela i in. 2009 - Trela M., Gierszewska D., Wardyński M., 2009 - Opracowanie badań sejsmicznych 3D - Temat Międzychód-Sieraków 3D - reprocessing i reinterpretacja. Archiwum Geofizyka Toruń Sp. z o.o.

Uliasz-Misiak B., 2007 - Polish hydrocarbon deposits usable for underground $\mathrm{CO}_{2}$ storage. Gospodarka Surowcami Mineralnymi, t. 23, z. 4, s. 111-120.

W a g n e r R., 1994 - Stratygrafia i rozwój basenu cechsztyńskiego na Niżu Polskim. Prace PIG, t. 146, s. 1-71.

W a g n e r R., 2000 - Charakterystyka facjalna i paleogeograficzna utworów dolomitu głównego. [W:] Kotarba M. (red.) Potencjał i bilans generowania utworów dolomitu głównego basenu permskiego Polski - Blok II. Arch. BG Geonafta, Warszawa.

Wagner i in. 2000 - Wagner R., Dyja czyński B., Papiernik B., Peryt T.M., Protas A., 2000 - Mapa paleograficzna dolomitu głównego-Ca2 w Polsce. [W:] Kotarba M.J. (red.) Bilans i potencjał węglowodorowy dolomitu głównego basenu permskiego Polski. Archiwum WGGiOŚ AGH, Kraków.

Wilk i in. 2002 - Wilk W., Fedorowicz A., Wilk M., Górski M., 2002 - Opracowanie badań sejssmicznych 3D rejon: Brońsko - Kościan (reinterpretacja). Archiwum Geofizyka Toruń Sp. z o.o. 


\title{
MOŻLIWOŚCI SEJSMICZNEJ IDENTYFIKACJI STREF AKUMULACJI GAZU W WAPIENIACH CECHSZTYNU MONOKLINY PRZEDSUDECKIEJ
}

\author{
Słowa kluczowe
}

Złoża gazu, badania sejsmiczne, cechsztyn, anomalie sejsmiczne, wskaźniki węglowodorowości

\section{Streszczenie}

Na obszarze monokliny przedsudeckiej złoża gazu występują w utworach węglanowych cyklotemów PZ1 (w wapieniu podstawowym Ca1) oraz PZ2 (w dolomicie głównym Ca2). Lokalizacja złóż jest ściśle związana ze strefami sedymentacji węglanów. Złoża występują przede wszystkim w obrębie stref barierowych oraz stref podnóża platform węglanowych. Wyrzut do chodnika rozdrobnionego materiału skalnego w KGHM ZG Rudna, który miał miejsce w 2009 r. pokazał, że gaz może występować również w strefie basenowej Ca1, z którą związane jest złoże miedzi.

Podstawową metodą badawczą wykorzystywaną do lokalizacji złóż węglowodorów są powierzchniowe badania sejsmiczne 2D i 3D. Ich sukcesy poszukiwawcze wynikają przede wszystkim z faktu zmniejszania się prędkości rozchodzenia się fal P oraz gęstości objętościowej pod wpływem nasycenia przestrzeni porowej gazem. Na skutek tego w rejestrowanym zapisie sejsmicznym widoczne są strefy zapisu anomalnego. Ich powiązanie ze złożami gazu, czyli złożowa interpretacja danych sejsmicznych, oparta jest na analizie DHI (Direct Hydrocarbon Indicator).

W prezentowanej pracy przedstawiono i porównano sejsmiczne odwzorowanie nasycenia gazem „,pułapek” zlokalizowanych w typowej barierze węglanowej (złoże Kościan w Ca1), w strefie podnóża platformy węglanowej (złoże Lubiatów w Ca2) oraz porowatej/szczelinowatej strefie dolomitu Ca1 w rejonie wyrzutu gazu, który miał miejsce w KGHM ZG Rudna.

Dla każdej ze stref opracowano, bazując na rejestrowanych danych geofizyki otworowej i modelowaniach 1D (sejsmogramy syntetyczne), kryteria identyfikacji stref nasyconych gazem.

Podstawowym kryterium wskazującym na nasycenie (1) bariery Kościan (Ca1) jest zmiana fazy refleksu (phase change) wiązanego ze spagiem Cal przy przejściu ze strefy basenowej (refleks ujemny) do strefy barierowej (refleks dodatni), (2) złoża Lubiatów, zlokalizowanego w obszarze podnóża platformy jest występowanie w stropie strefy nasyconej silnego refleksu ujemnego (bright spot), (3) porowatej i szczelinowej strefy głębokowodnej w ZG Rudna - występowanie w spągu dolomitów Ca1 refleksu o amplitudzie zbliżonej do zera.

Opracowane kryteria są kryteriami lokalnymi, zbyt duża jest bowiem zmienność budowy geologicznej w różnych częściach basenu cechsztyńskiego.

\section{A POSSIBILITY OF SEISMIC IDENTIFICATION OF GAS ACCUMULATIONS IN ZECHSTEIN CARBONATE FORMATIONS} OF THE FORE-SUDETIC MONOCLINE

$$
\text { Key words }
$$

Gas deposits, seismic survey, Zechstein limestone, seismic anomalies, Direct Hydrocarbon Indicators

\section{Abstract}

In the Fore-Sudetic Monocline area, gas deposits occur in carbonate rocks of cyclothems PZ1 (Zechstein limestone Ca1) and PZ2 (main dolomite Ca2). The location of deposits is closely connected with zones of carbonate sedimentation. Generally, gas deposits occur within barrier zones and at the foot of carbonate platforms. The outburst of rock fragments into the heading of the KGHM Rudna mine in 2009 was evidence that gas could also appear in the basin zone $\mathrm{Ca} 1$ of the copper deposit. 
2D and 3D surface seismic surveys comprise the basic method which is applied to hydrocarbon prospecting. The main advantage of this method is the fact that P-wave velocity and bulk density decrease as a result of gas saturation of the pore spaces. As a result, one can observe anomalous seismic [records(activity?)] which can be connected with gas deposits, and reservoir interpretation of seismic data is based on Direct Hydrocarbon Indicators analysis (DHI).

This paper presents and compares seismic images of gas saturation [in traps(trapped?)] in a typical carbonate barrier (Koscian gas field in Ca1) at the foot of a carbonate platform (Lubiatów gas field in Ca2), and in a porous/fractured zone in Ca1 dolomite where there was a gas outburst in the Rudna mine. Based on available well logging data and 1D seismic modeling (synthetic seismograms) this study developed criteria for identification of gas-saturated zones for each case.

The results of the study provide the following basic criteria for gas saturation: (1) phase change at Ca1 bottom from negative at the basin zone to positive at the barrier zone - for the Kościan barrier Ca1; (2) the bright spot at the top of the saturated zone - for the Lubiatów deposit at the foot of the carbonate platform; (3) reflections with close to zero amplitude at the bottom of Ca1 dolomites - for the porous and fractured deep-water zone of the Rudna mine. 